\title{
Seasonal Changes in Water Quality Parameters and Sediment Nutrients in Jagadishpur Reservoir, a Ramsar Site in Nepal
}

\author{
Biraj Gautam and Bikash Bhattarai \\ Central Department of Environmental Science \\ Tribhuvan University, Kirtipur, Kathmandu \\ e-mail: jibiraaj@gmail.com
}

\begin{abstract}
Physical and chemical characteristics of waters in reservoirs are influenced by seasonal fluctuations in water and also by agricultural runoff. Such fluctuations are more frequent in Jagadishpur reservoir where rain events are strongly seasonal. To carry out the study, water samples were collected from six sites where as the soil samples were taken from four sites in four seasons (winter, spring, monsoon and autumn) in 2006. The soil and water nutrients both varied seasonally affecting the productivity of the reservoir. The productivity of the reservoir was maximum in monsoon and minimum in autumn. The release of phosphorus and nitrogen from the lake sediment to water column plays a key role in determining the nutrient level in reservoirs. The reservoir was found to be polytrophic: eutrophic on the basis of transparency and total nitrogen and hypereutrophic on the basis of phosphate concentration.
\end{abstract}

Key words: productivity, polytrophic, eutrophic, hypereutrophic

\section{Introduction}

Nepal's wetland habitat is created through varied water bodies that range from permanent flowing rivers to seasonal streams, low land ox-bow lakes, high altitude glacial lakes, swamps, marshes, paddy fields, reservoirs and ponds (Bhandari 1992). Lowlands of Nepal boats the most extensive wetland systems which include river systems, marshes, ox-bow lakes, ponds, man-made reservoirs and paddy fields. The ecological diversity of wetlands systems is reflected in the great variety of wetlands flora and fauna (BPP 1995). These areas provide various products such as live stock grazing, fisheries, recreation and the conservation of the biology, fodder and timber and are sites for feeding and breeding for various species of resident and migratory birds (Sah 1997). Wetland sites including Jagadishpur Reservoir (a Ramsar site) are highly prioritized wetlands of lowland Nepal to prevent deterioration of the myriad ecological (biodiversities) functions and values (BPP 1995).

Physical, chemical and biological features in reservoirs are influenced by seasonal surface level fluctuations, which are significantly associated with anthropogenic utilizations (Wetzel 1990, Geralds \& Boavida 2005). Such fluctuations are more frequent in reservoirs located in regions where rain events are strongly seasonal and occur in an irregular precipitation regime (Geralds \& Boavida 2005).
The broad objective of this investigation is to asses the relationship between the water and sediment characteristics to assess the limnological status of the reservoir in order to suggest the appropriate measures for conservation practices. The specific objectives are (a) to assess and understand seasonal variation of water quality of Jagadishpur reservoir and (b) to assess the trophic status of the reservoir and nutrient availability in the sediments.

\section{Study Area}

The Jagadishpur reservoir is situated approximately $4.8 \mathrm{~km}$ east of Banganga River $10 \mathrm{~km}$ north of Taulihawa, district headquarter of Kapilbastu and 8 $\mathrm{km}$ south of Banganga bridge along the eastern embankment road, Niglihawa VDC, Kapilbastu District, Lumbini zone, at geographical coordinates of $27^{\circ} 35^{\prime} 00.0^{\prime \prime} \mathrm{N}$ and $83^{\circ} 05^{\prime} 00.0^{\prime \prime} \mathrm{E}$ (DNWPC-IUCN 2002) (Fig. 1).

The reservoir is constructed for irrigation purpose and is harnessed by rock fill dike. Its surface area is approximately 157 ha at full storage level with a total shoreline perimeter of approximately $5 \mathrm{~km}$. At FSL (EL $110 \mathrm{~m}$ ) the storage capacity is $45^{*} 106 \mathrm{~m}^{3}$ with a maximum depth adjacent to the dam wall and average depth 3m (Srivastav 2006). The dam has a selective depth discharge system ensuring the best quality water 
is released through the withdrawal outlet to meet farmland irrigation and downstream needs. An earthen dike runs north to south from the centre of the reservoir. The eastern part has shallow water body whereas the western part of the reservoir is deeper and completely covered by water.

The main riverine input to the lake is the Banganga river from the west of the reservoir. The average annual rainfall in the catchments approximately ranges from 1818 to $2520 \mathrm{~mm}$. It is expected to be less than 2000 $\mathrm{mm}$ in the northern part and in the foothills, the annual rainfall is expected to be above $2500 \mathrm{~mm}$ (averaged over the last fourteen years, DHM 2005), with 88 percent of the rainfall was limited within the months of June to September.

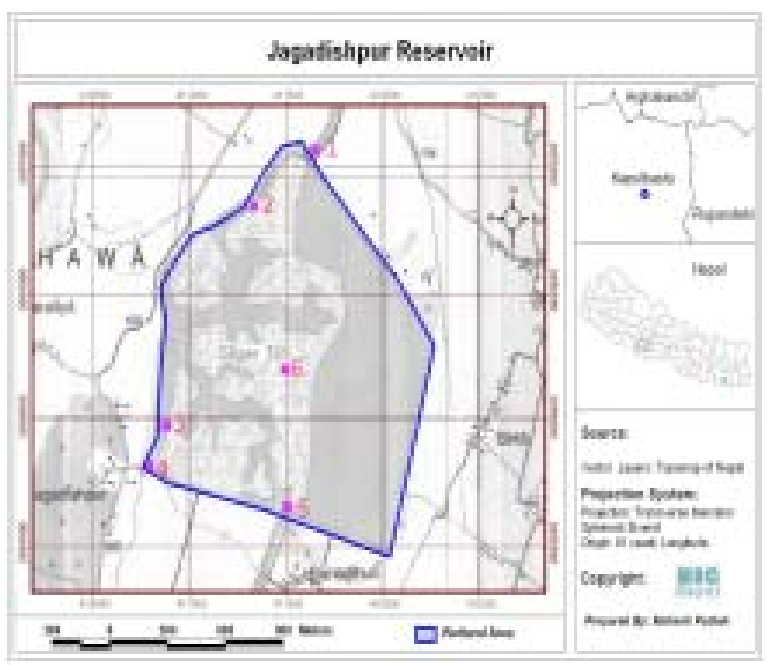

Fig. 1. Study area showing sampling sites

\section{Materials and Methods}

\section{Experimental design}

For the analyses, four sites were selected to carry out water and soil sampling (Sites 1,3,4 and 5) along with two additional sites (Sites 2 and 6) for the water alone. Both water and soil samples were taken for four seasons (winter, spring, monsoon and autumn) once in each season in 2006. The sampling date and time were selected in such a manner that the impacts of rainfall was minimum (samplings during rainfall or immediately after the flooding were avoided).
Site 1: This site was selected in feeding canal to the reservoir, about $70 \mathrm{~m}$ distance from the confluence of the reservoir during its lower water level (at the time of pilot survey). Its sandy bottom consisted predominantly gravels and sand. Occasional occurrence of green algae was attached with stones.

Site 2: It is located in the confluence of feeding canal. Its muddy bottom was made of clay, silt and sand with dominance of macrophytes.

Site 3: This site was selected in the southern outlet of the reservoir. Its muddy bottom consisted of clay, silt and sand with little macrophytes.

Site 4: This site was located inside and within the south eastern outlet of the reservoir. Its muddy bottom consisted of high level of organic matter, clay, silt and sand, with seasonal macrophytes.

Site 5: This site was selected in the reservoir within the main outlet. Its muddy bottom consisted clay, silt, sand and gravels, with seasonal macrophytes. Eastern dike was covered with planted trees.

Site 6: This site represented the middle of the reservoir south to the island. Its muddy bottom consisted of clay, silt, sand with seasonal macrophytes. The island was covered with terrestrial and swampy vegetation.

These sites were selected so that they could represent the overall conditions of the reservoir- canal, inlet (transition between lentic and lotic), reservoir (center of the reservoir) and outlet.

\section{Field and laboratory measurements}

Discrete grab samples were taken from the predetermined sites at a depth of $0.5 \mathrm{~m}$. Water samples were taken with the help of Freindinger Water Sampler (Ruttner) of diameter $8 \mathrm{~cm}$, length $60 \mathrm{~cm}$ and capacity of $500 \mathrm{ml}$ after flushing it in situ for three times. The initial idea to analyze water quality parameters (DO and Temp) along the water depths was not feasible due to shallowness of the reservoir and also the data collected in different depth did not vary significantly. Therefore the samples were taken only from a depth of $0.5 \mathrm{~m}$ from the surface to overcome with the possible interferences on the surface and to represent the best condition prevailing at the sites. Clean plastic bottles of different sizes $(500 \mathrm{ml}$ and $1000 \mathrm{ml})$ were used to collect the various samples. These sampling bottles were rinsed twice with respective water samples and filled air tight. All the sampling bottles were marked and kept in ice boxes. For the determination of potassium, the sample 
was adjusted to $\mathrm{pH}$ less than 2 with the help of nitric acid. The bottom sediment samples were taken with the help of Grab Sampler (Van Veen Grab with sampling area $0.025 \mathrm{~m}^{2}$, Wagtech Company). The parameters like temperature, $\mathrm{pH}$, transparency, dissolved oxygen, free carbondioxide were measured immediately on the site at the time of sampling and the parameters like alkalinity, hardness, and chloride were measured within few hours after collection of samples. The other parameters were determined in the laboratory where the samples are preserved in refrigerator (Kelvinator, Model KCF 0310 OS). The above mentioned processes were followed to collect the water samples throughout the study period.

\section{Physico-chemical analysis of water}

All the physico-chemical parameters (except total nitrogen) were determined according to the methods described in APHA, AWWA, WEF (1998). The total nitrogen was determined according to the methods described in Trivedy and Goel (1984).

\section{Soil laboratory analysis}

All the analyses were done following the standard methods given by Trivedi \& Goel (1984) except triangular classification of soil and mineral identification. For the triangular soil classification USDA particle soil classes (Goldman et al. 1986) and for mineral identification and composition, counting method given by Pettijohn (1984) was used.

\section{Results and Discussion}

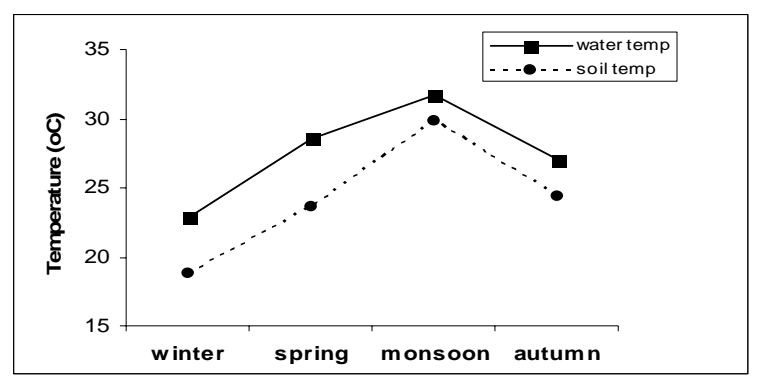

Fig. 2. Seasonal variation of temperature

The water temperature was maximum $\left(31.67 \pm 2.25^{\circ} \mathrm{C}\right)$ in monsoon and was least in winter $\left(22.83 \pm 1.32^{\circ} \mathrm{C}\right)$. There was distinct seasonal variation in the surface water temperature (Fig. 2). This change in water temperature was directly related with soil temperature, as they showed perfect correlation $(r=0.96)$. Temperature is a factor of great importance for aquatic ecosystems as it affects the organisms as well as physical and chemical characteristics of water (Delince 1992, Abdo 2005). Water temperature regulates ecosystem functioning both directly through physiological effects on organisms, and indirectly, as a consequence of habitat loss. Water temperature showed positive correlation with $\mathrm{pH}$ and conductivity and negative with DO and the data obtained in the study also followed the pattern as observed in the

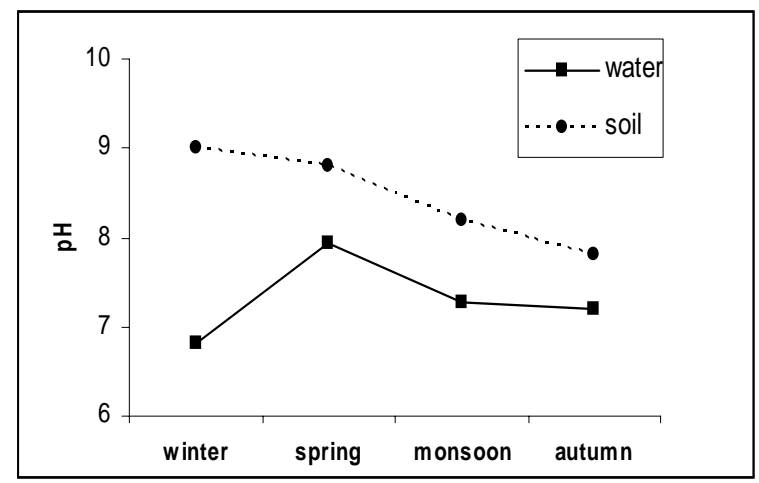

Fig. 3. Seasonal variation of $\mathrm{pH}$

Gaindahawa lake (Simkhada 2003). Transparency of water column differed seasonally in the reservoir. It was maximum in winter $(2 \pm 0.41 \mathrm{~m})$ and minimum in monsoon $(0.71 \pm 0.45 \mathrm{~m})$. The reported lowest Sechi disk measurements especially at sites 3 and 4 in monsoon were probably due to the added influence of wind induced mixing result in sediment resuspension from the more shallow water. The low water transparency in the reservoir is attributed to a large suspended matter load, in the form of soil particles in monsoon making the water more turbid. Similar results were also observed by Mwaura (2003) who studied various shallow reservoirs in Kenya and found polytrophic natures of lakes based on the trophic classification. The value of $\mathrm{pH}$ both in water and soil did not fluctuate much through out the study period. Generally, water with low levels of carbonates, bicarbonates and phosphates had low buffering capacity (Agrawal 1999). So, the fluctuation in $\mathrm{pH}$ in the study was very less (Fig. 3) which may be due to the presence of sufficient amount of bicarbonate alkalinity. The value of alkalinity $(285.08 \pm 33.98 \mathrm{mg} / \mathrm{l})$ in water was maximum in autumn and minimum (128.33 \pm 64.86 $\mathrm{mg} / \mathrm{l}$ ) in monsoon. This result supports the findings of Gaindahawa Lake (Simkhada 2003). The increase in bicarbonate during autumn and winter may be attributed to the decrease in air and water temperatures, leading 
to the decrease in the reaction rate confirming the findings of Abdo (2005).

The dissolved oxygen (DO) was maximum $(8.72$ $\pm 1.62 \mathrm{mg} / \mathrm{l})$ in winter and minimum $(5.12 \pm 0.91 \mathrm{mg} / \mathrm{l})$ in monsoon (Fig. 4). The DO was positively correlated with transparency $(r=0.9)$ and negatively correlated with water temperature $(r=-0.86)$. The seasonal patterns of DO in tropical reservoirs are likely to differ from their temperate counterparts because warm tropical waters are more susceptible to oxygen depletion. This may be due to the reduced solubility of oxygen in warm waters coupled with higher rates of microbial metabolism.

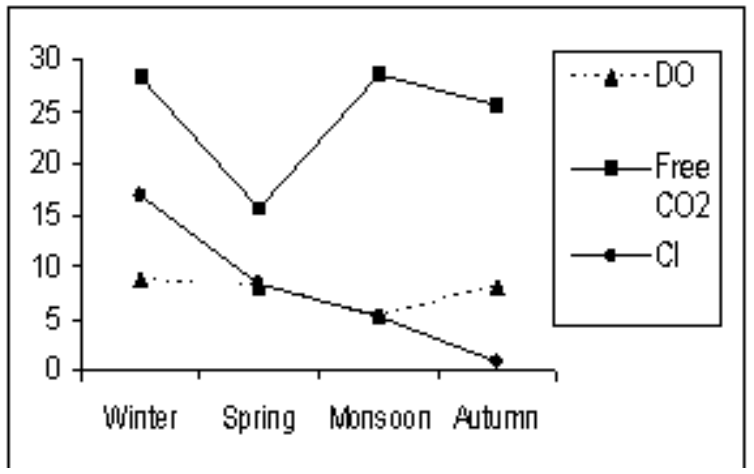

Fig.4. Seasonal variation of water parameters in $\mathrm{mg} / \mathrm{l}$

The maximum value of conductivity in water was $409 \pm 72.45 \mu \mathrm{S} / \mathrm{cm}$ in winter and lowest of $359 \pm 82.52$ $\mu \mathrm{S} / \mathrm{cm}$ in spring (Fig. 5). Similar trend was also observed in the same reservoir by Mc Eachern (1996).

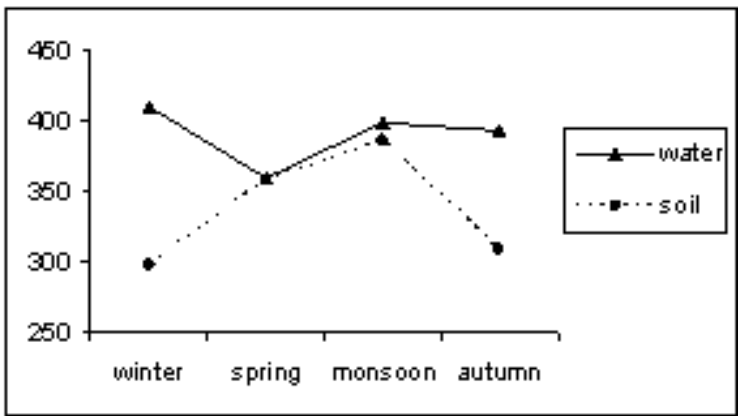

Fig. 5. Variation of conducitvity $(\mu \mathrm{S} / \mathrm{cm})$

However, the maximum of $385.6 \mu \mathrm{S} / \mathrm{cm}$ in monsoon and minimum of $297 \mu \mathrm{S} / \mathrm{cm}$ in winter was observed in case of sediment. The highest value of chloride was observed in winter $(16.89 \pm 3.87 \mathrm{mg} / \mathrm{l})$ and minimum in autumn $(0.75 \pm 0.13 \mathrm{mg} / \mathrm{l})$.
The relative decrease in chloride concentration during the hot period especially in autumn may be due to dilution after rainy season. The highest value of it during the winter may be due to reduction of water level in the reservoir.

The soil type falls under the category of sand and loamy sand on the basis of triangular classification. The sediments at the inlet of the reservoir consists of sand with more than 90 percent of sand particles and other parts of the reservoir have loamy sands with more than 10 percent of clay and 30 percent of silt. The mineral composition of bottom sediment of the reservoir consists of about 43 percent of rock fragments, 30 percent of quartz, 16 percent of feldspar and remaining includes others, which were not identified (Fig. 6).

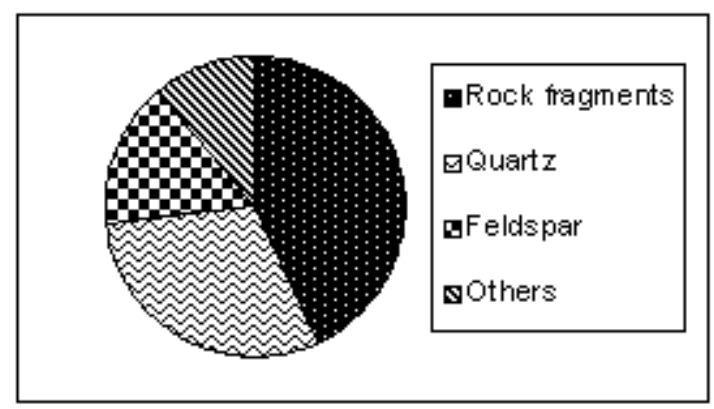

Fig. 6. Mineral composition of sediment

Except the inlet of the reservoir, other parts have high degree of finer material. Texture of sediment will determine the type and abundance of macrophyte species that can survive in a location (Barko \& Smart 1986). Xu et al. (2003) have mentioned that the concentration of TN and TP declined with the increase in lake sediment size diameter. The availability of mineral nutrients for growth is highest in sediments of intermediate density, such as silt (Barko \& Smart 1986).

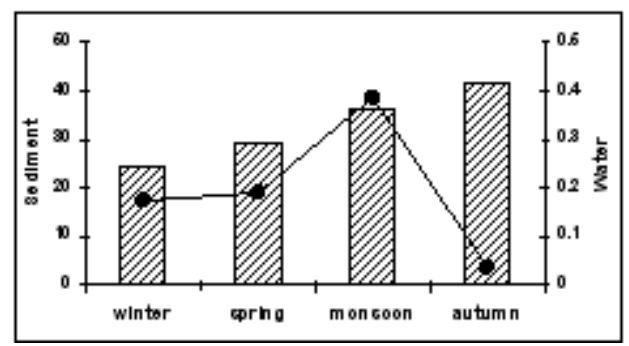

Fig. 7. $\mathrm{PO}_{4}^{--}(\mathrm{mg} / \mathrm{l})$ in sediment (Bar)and water(line) 
Redox potential, $\mathrm{pH}$ and sorption/desorption processes have been considered important factors regulating the exchange of nutrients between sediment and the bottom of the water column (Goedkoop \& Pettersson 2000, Watts 2000). Hu et al. (2001) showed that higher $\mathrm{pH}$ and anaerobic conditions ( $\mathrm{Eh}<+100 \mathrm{mV}$ ) in the overlying water greatly stimulated $\mathrm{P}$ release from bottom sediments. Calcium $\left(\mathrm{Ca}^{++}\right)$concentration in combination with temperature and $\mathrm{pH}$ can induce precipitation from the water column and enhance sediment adsorption (Burley et al. 2001).

The concentration of soil phosphate $\left(\mathrm{PO}_{4}^{-}\right)$varied seasonally. Its maximum value $(41.75 \mathrm{mg} / \mathrm{l})$ was observed in autumn whereas the minimum value $(24.36$ $\mathrm{mg} / \mathrm{l}$ ) in winter (Fig. 7). The lake bottom acts as a sink for TP instead of as a source. The behavior of the balance of $\mathrm{PO}_{4}^{--}$, however, is the opposite, the sediment being a source of this nutrient to the lake (Anda et al. 2001). Internal phosphorus recycling from bottom sediments to the euphotic zone can initiate and sustain both algal

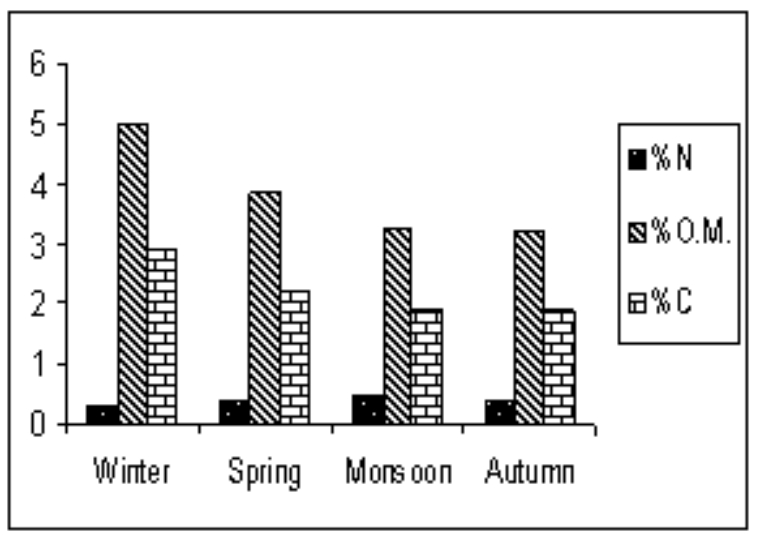

Fig. 8. Sediment characteristics

blooms and eutrophication, even when external $\mathrm{P}$ sources decreased (Welch \& Cooke 1995, Boers et al. 1998, Harremoes 1998). Thus, the control of eutrophication depends on both Pretention in the bottom sediments and Premoval from the water column (Welch \& Cooke 1995, Boers et al. 1998, Burley et al. 2001). The recycling of $\mathrm{P}$ from the sediments into the water column involves the solution of sediment bound $\mathrm{P}$ into pore water then to overlying water column (Bostrom et al. 1982, Burley et al. 2001).

The percentage $\mathrm{N}$ in soil varied seasonally showing maximum of 0.479 in monsoon and minimum of 0.294 in winter (Fig. 8). According to Martinova (1993), the $\mathrm{N}$ concentration in the sediments is controlled by the presence of organic matter, with $90 \%$ (or even more) of the $\mathrm{N}$ in the sediment existing in organic forms. The higher the organic matter content in sediment, the lower is the alkaline phosphorus activity (Venkateswaran \& Natarajan 1983, Jin et al. 2006). Based on Healey and Hendzel (1979) for N deficiency criterion ( $\mathrm{C}: \mathrm{N}$ ratio $<9$ no deficiency, $9-15$ moderate and $>15$ severe) the reservoir was no deficiency in most of the time.

The maximum concentrations of $\mathrm{NO}_{3}^{-}(200.66 \pm$ $55.04 \mu \mathrm{g} / \mathrm{l})$ and $\mathrm{PO}_{4}-(387.33 \pm 199.34) \mu \mathrm{g} / \mathrm{l}$ in water were observed in monsoon whereas the minimum value of $\mathrm{NO}_{3}{ }^{-}(56.16 \pm 19.13 \mu \mathrm{g} / \mathrm{l})$ was observed in winter and $\mathrm{PO} 4-(36.10 \pm 0.9 \mu \mathrm{g} / \mathrm{l})$ in autumn. The highest value of $\mathrm{PO}^{-}$- in monsoon may be due to the autochthonous sources, as the value in the water of incoming cannel is lower and similar to other seasons. This result is supported by Scheidt and Nichols (1976). The higher values of nitrate may be attributed to the oxidation of ammonia by nitrifying bacteria and biological nitrification (Seike et al. 1990, Abdo 2005) whereas the lower values may be related to the denitrification of nitratenitrogen by denitrifying bacteria (Merck 1980, Abdo 2005). The high concentration of dissolved inorganic nitrogen in the surface sediments result in diffusion of these nutrients into the overlying water (UNEP-IETC 1999). The algae can utilize inorganic nitrogen compounds such as nitrate, nitrite and ammonium as well as organic nitrogenous compounds like urea, uric acid and amino acids for their nitrogen needs (Agrawal 1999).

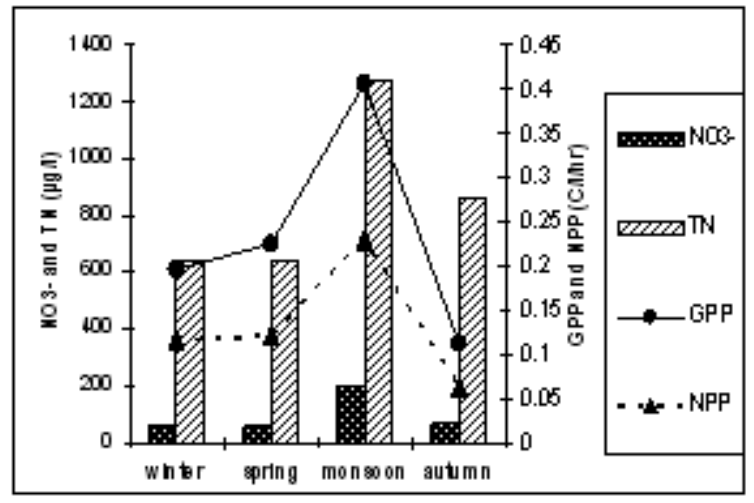

The concentration of total nitrogen (TN) was maximum $(1274 \pm 103.65 \mu \mathrm{g} / \mathrm{l})$ in monsoon and minimum $(640.5 \pm 228.44) \mu \mathrm{g} / \mathrm{l}$ in winter (Fig. 9). The TN also varied seasonally showing a strong positive relation with 
nitrates and phosphates in water. Agricultural runoff is considered as the most significant cause of nutrient enrichment in the reservoir. Experience from mainly deep stratified lake suggests that nitrogen Fig. 9. Variation of nutrients and productivity may limit growth and trigger dominance by nitrogen fixing cyanobacteria at low inorganic $\mathrm{N}$, when the total nitrogen: total phosphorus (TN: TP) ratio declines below 10-20 (Smith 1983). In shallow, well-mixed, north temperate lakes, the pattern is less clear as green algae often dominate at high nutrient loading, despite TN : TP ratios well below 10 (Jensen et al. 1994). Nitrogen ( $\mathrm{N}$ ), while not considered the limiting nutrient in most cases for freshwater lakes, is nonetheless an essential nutrient for algal and rooted plant growth (Wetzel 2001).

The maximum gross primary productivity (GPP) of $0.40 \mathrm{mg} \mathrm{C} / \mathrm{l} / \mathrm{hr}$ and net primary productivity (NPP) of $0.23 \mathrm{mg} \mathrm{C} / \mathrm{l} / \mathrm{hr}$ were observed in monsoon. Similarly, the minimum value of GPP $(0.11 \mathrm{mg} \mathrm{C} / \mathrm{l} / \mathrm{hr})$ and NPP (0.06 $\mathrm{mg} \mathrm{C} / \mathrm{l} / \mathrm{hr}$ ) was found in autumn. The seasonal variation in present study is strongly correlated with the $\mathrm{NO}_{3}^{-}$and $\mathrm{PO}^{-}-$. So the primary productivity in the reservoir seems to be determined by these nutrients.

It is a well-known phenomenon that the seasonal dynamics of nutrient availability in deep, stratified lakes differs profoundly from the general pattern observed in shallow lakes (Straskraba et al. 1993, Scheffer 1998). For shallow lakes, the intense sediment-water contact, as well as the increased mineralization rates resulting from the relatively high sediment temperatures, leads to an increased level of nutrients from the sediment (Jeppesen et al. 1991, Tuzun \& Mason 1996, Beklioglu et al. 2003).

The reservoir was classified as Oligotrophic by Mc Eachern (1996) on the basis of TN and TP and also by DNWPC on the basis of chlorophyll-a content present in water in 2002. The nutrients level has increased several folds during the single decade which can be explained by the nutrient levels observed in the present study, according to which, the lake is eutrophic on the basis of transparency and total nitrogen. However, the abundant presence of phosphorus (orthophosphate in the present study) shows the hypereutrophic status of he reservoir.

The quality parameters of water showed productive nature of reservoir water as it witnessed excess growth of macrophytes. The trophic status of the lake was found to be hypereutrophic based on phosphate and eutrophic based on Sechi disk transparency and total nitrogen. Though the concentrations of general water parameters do not seem to pose any threat to the existing condition of the reservoir, the nutrients level which has already been increased by more than ten folds within a single decade is sure to degrade the condition of the reservoir soon in future. Some gestures of the threats can be observed in the form of plant productivity in water column or on the bottom substratum which is likely to be connected with the consequences of the agricultural runoff.

It looks quite necessary to carry out further studies in the reservoir focusing on the following components:

- Effects of agricultural runoff in changing the nutrient status of the reservoir and

- The growth and pattern of aquatic macrophytes with especial emphasis on the alien invasive species.

\section{Acknowledgement}

We are thankful to Prof. Dr. Umakant Ray Yadav, Head of Cental Department of Environmental Science, T.U., Kirtipur, for providing lab facilities. We are also very much grateful to Asso. Prof. Paras M. Acharya and Mr. Naresh Rimal for their valuable guidance and support.

\section{References}

Abdo, M.H. 2005. Physicochemical characteristics of Abuza'baal ponds, Egypt. Egyptian Journal of Aquatic Research 31(2): 1-15.

Agrawal, S.C. 1999. Limnology. A.P.H. Publishing Corporation, New Dehi, India.

Anda, J.D., H. Shear, V. Maniak and G. Riedel. 2001. Phosphorus in lake Chapala. Lakes and Reservoirs: Research and Management 6:313-321.

APHA, AWWA, WEF. 1998. Standard methods for examination of water and wastewater $\left(20^{\text {th }}\right.$ edition). American Public Health Association, Washington, DC.

Barko, J.W. and R.M. Smart. 1986. Sediment related mechanism of growth limitations in submersed macrophytes. Ecology 67:1328-1340.

Beklioglu, M., O. Ince and I. Tuzun. 2003. Restoration of the eutrophic Lake Eymir, Turkey, by biomanipulation after a major external nutrient control I. Hydrobiologia 489: 93-105.

Bhandari, B. 1992. The current status of wetlands in Nepal. Country report presented at the Asian wetland 


\section{B. Gautam \& B. Bhattarai /Seasonal Changes in Water Quality.}

symposium organized by Ramsar Centre Japan (14-20 October 1992), Otsu-Kushiru, Japan.

Boers, P., W. Van Raaphorst and D.T. Van der Molen. 1998. Phosphorus retention in sediments. Water Science and Technology 37: 31-39.

Bostrom B., M. Jansson and C. Forsberg. 1982. Phosphorus release from lake sediments. Archiv fur Hydrobiologie Beiheft Ergebnisse Limnologie 18: 5-59.

BPP. 1995. Biodiversity assessment of terai wetlands (Ed. W.J.M Verheugt.). Biodiversity profiles project technical publication no. 1. Department of National Parks and Wildlife Conservation. Ministry of Forest and Soil conservation. Government of Nepal, Kathmandu. pp 1-75

Burley, K. L, E E .Prepas and P.A. Chambers. 2001. Phosphorus release from sediments in hard water eutrophic lakes: The effect of redox sensitive and insensitive chemical treatments. Freshwater Biology 46: 1061-1074.

Delince, G. 1992. The ecology of fish pond ecosystem with reference to Africa. Kulwer Academy Publisher.

DHM, 2005 Daily precipitation records of Lumbini zone from 1990-2004. Department of Hydrology and Meteorology, Babarmahal, Kathmandu, Nepal (unpublished).

DNWPC-IUCN. 2002. Ramsar Information Sheet (RIS), www.ramsar.org

Geraldes, A.M. and M.J. Boavida. 2005. Seasonal water level fluctuations: Implications for reservoir limnology and management. . Lakes \& Reservoirs: Research and Management 10: 59-693.

Goedkoop, W. and K. Pettersson. 2000. Seasonal changes in sediment phosphorus forms in relation to sedimentation and benthic bacterial biomass in lake Erken. Hydrobiologia 431: 41-50.

Goldman, S.J., A. Jakson and T.A. Bursstynsky. 1986. Erosion and sediment control handbook. Mc Graw-Hill Book Company.

Harremoes, P. 1998. The challenge of managing water and material balances in relation to eutrophication. Water Science and Technology 37: 9-17.

Healey, F.B. and L.L. Hendzel. 1979. Indicators of phosphorus and nitrogen deficiency in five algae in culture. Journal Fisheries Research Board Canada 36:1364-1369.

Hu, Q., J. Song, L. Dong, Z. Li and Y. Zhu. 2001. Effects of $\mathrm{pH}$ and $\mathrm{Eh}$ on nitrogen and phosphorus release from sediments of West Lake. In Proceedings of the $9^{\text {th }}$ International Conference on the Conservation and Management of Lakes; September 2001, Biwako, Japan. ILEC, Shiga, Japan.

Jensen, J.P., E. Jeppesen., K. Olrik and P. Kristensen. 1994. Impact of nutrients and physical factors on the shift from cyanobacterial to chlorophyte dominance in shallow Danish lakes. Canadian Journal of Fisheries and Aquatic Sciences 51:1692-1699.

Jeppesen, E., P. Kristensen, J.P. Jensen, M. Sondergaard, E. Mortensen and T.L. Lauridsen. 1991. Recovery resilience following a reduction in external phosphorus loading of shallow, eutrophic Danish lakes: Duration, regulating factors and methods for overcoming resilience. Memorie dell'Istituto Italiano di Idrobiologia 48: $127-48$.

Jin, X. C., S. R. Wang, H. C. Zhao, Q. Y. Bu, J. Z. Chu, Z. Cui, X. N. Zhoul and F. N. Wu. 2006. Effect of lake sediments of different trophic states on alkaline phosphates activity. Lakes \& Reservoirs: Research and Management 11: 169-176.

Martinova, M.V. 1993. Nitrogen and phosphorus compounds in bottom sediments: Mechanisms of accumulation, transformation and release. Hydrobiologia 252: 1-22.

Mc Eachern, P. 1996. Regional and seasonal characteristics of water chemistry, Algal Biomass and Nutrient limitations in lakes of Nepal. M.Sc. thesis, Faculty of the graduate of school, University of MissouriColumbia.

Merck, E. 1980. Complexmetric Assay Methods Titriplex. Germany.

Mwaura, F. 2003. The spatio-temporal characteristics of water transparency and temperature in shallow reservoirs in Kenya. Lakes and Reservoirs: Research and Mangement 8:259-268.

Pettijohn, S.J. 1984. Sedimentary rocks. ( $3^{\text {rd }}$ Edition). CBS publisher and distributors, Delhi, India.

Sah, J.P. 1997. Koshi tappu wetlands: Nepal's Ramsar Site. IUCN Bangkok, Thailand. pp. 1-5

Scheffer, M. 1998. Ecology of shallow lakes. (1 ${ }^{\text {st }}$ Edition). Chapman \& Hall, London.

Scheidt, R.C. and J.L. Nichols. 1976. Physicochemical and biological characteristics of hill creek reservoir. Water Resources Research Institute, Corvallis, Oregon.

Seike, Y. J., K. Kondo, H. Hashihitani, M. Okumura, K. Fujinaga, and Y. Date. 1990. Nitrogen metabolism in the brackish Lake Nakanoum. IV: Seasonal of nitratenitrogen. Japan Journalof Limnology. 51 (3): 137-147

Simkhada, D. 2003. Ecology and management issues of Gindahawa lake, Rupendehi, Nepal. M. Sc. Thesis. Central Department of Botany, Tribhuvan University, Kathmandu.

Smith, V. H. 1983. Moderate nitrogen to phosphorus ratios favors dominance by blue-green algae in lake phytoplankton. Science 221: 669-671.

Srivastav, R. 2006. Technical report of Jagadishpur reservoir. In: Bishwo simsar Chhetra Jagadishpur reservoir (Ed N. Poudel) Lumbini Kapilbastu Bachau Abhiyan pp. 30-42.(Nepali)

Straskraba, M., J.G. Tundisi and A. Duncan. 1993. State-of the- art of reservoir limnology and water quality 
management. In: Comparative reservoir limnology and water quality management. Chapter XIII (eds M. Straskraba, J. G. Tundisi \& A. Duncan). Kluwer Academic Publishers, the Netherlands pp. 213-88.

Trivedi, R. K. and P. K. Goel. 1984. Chemical and biological methods for water pollution studies. (1 st Edition) Environmental publications, KARAD (India).

Tuzun, I. and C. F. Mason. 1996. Eutrophication and its control by biomanipulation: An enclosure experiment. Hydrobiologia 331: 79-95.

UNEP-IETC, 1999. Planning and management of lakes and reservoirs: An integrated approach to eutrophication. Osaka, Japan. pp 175-290.

Venkateswaran, K. and R. Natarajan 1983. Distribution of phosphatase in sediments of Porto Novo. Indian J. Mar. Sci. 12: 231-2.
Watts, C. J. 2000. The effects of organic matter on sedimentary phosphorus release in an Australian reservoir. Hydrobiologia 431:13-25.

Welch, E. B. and G. D. Cooke 1995. Internal phosphorus loading in shallow lakes: Importance and control. Lake and Reservoir Management 11:273-281.

Wetzel, R. G. 1990. Reservoir ecosystems: Conclusions and speculations. In: Reservoir Limonology: Ecological Perspectives (eds K. W. Thornton, B. L. Kimmel \& F. E. Payne) pp. 227-38, 46. Wiley, New York.

Wetzel, R.G. 2001. Limnology lake and river ecosystems. (3rd Edition) Academic press, San diego pp 1006.

Xu, F., S. Tao, R. W. Dawson. and Z. R. Xu. 2003. The distribution and effects of nutrients in the sediments of a shallow eutrophic Chinese lake. Hydrobiology 429: 85-93. 